\title{
PKM PELATIHAN MENCUCI TANGAN MENGGUNAKAN SABUN SEBAGAI PERILAKU HIDUP BERSIH DAN SEHAT UNTUK MASYARAKAT RT 007/RW 007 DESA PANGKALAN JATI, KECAMATAN CINERE KOTA DEPOK
}

\author{
Tiwuk Susantiningsih $^{1}$, Retno Yuliyanti ${ }^{1}$, Kristina Simanjuntak ${ }^{1}$, Arfiyanti $^{1}$ \\ ${ }^{1}$ Dosen Tetap Fakultas Kedokteran, Universitas Pembagunan Nasional "Veteran” Jakarta \\ Email: tiwuksusantiningsih@gmail.com, retnoyuliyanti@gmail.com,kristin_juntak@yahoo.com, arfiyanti@gmail.com
}

\begin{abstract}
ABSTRAK
Perilaku Hidup Bersih dan Sehat (PHBS) adalah upaya untuk memberikan pengalaman belajar atau menciptakan suatu kondisi bagi perorangan, kelompok dan masyarakat, dengan membuka jalur komunikasi, memberikan informasi dan edukasi untuk meningkatkan pengetahuan, sikap dan perilaku, sehingga membantu masyarakat mengenali dan mengatasi masalah sendiri, agar dapat menerapkan cara-cara hidup sehat dalam rangka menjaga dan meningkatkan kesehatan. Tim Pengabdian Kepada Masyarakat Fakultas Kedokteran Univesitas Pembangunan Nasional "Veteran” Jakarta telah melakukan pelatihan cara mencuci tangan menggunakan sabun sebagai salah satu perilaku hidup bersih dan sehat untuk dapat mencegah berbagai penyakit yang diakibatkan oleh higienitas yang kurang di TPA RT 007/RW 007 Kelurahan Pangkalan Jati Kecamatan Cinere Kota Depok. Jumlah responden yang datang dan mengikuti pelatihan sebanyak 42 orang. Penyuluhan dan pelatihan menggunakan media powerpoint penyuluhan dan brosur cara mencuci tangan menggunakan sabun. Hasil penilaian nilai pretest sebesar 76,49\% dan setelah dilakukan penyuluhan dan pelatihan, kemudian dilakukan posttest. Dapat dilihat bahwa nilai posttest responden meningkat menjadi 96,73\%. Terjadi peningkatan sebesar 20,24\%. Hal ini sesuai dengan harapan Tim Pengabdian bahwa diharapkan terjadi peningkatan pengetahuan dan ketrampilan sebesar $20 \%$.
\end{abstract}

Keywords: Anak anak TPA, Cuci tangan memakai sabun, PHBS.

\section{PENDAHULUAN}

Perilaku Hidup Bersih dan Sehat (PHBS) adalah upaya untuk memberikan pengalaman belajar atau menciptakan suatu kondisi bagi perorangan, keluarga, kelompok dan masyarakat, dengan membuka jalur komunikas, memberikan informasi dan edukasi untuk meningkatkan pengetahuan, sikap dan perilaku, sehingga membantu masyarakat mengenali dan mengatasi masalah sendiri, dalam tatanan rumah tangga, agar dapat menerapkan cara-cara hidup sehat dalam rangka menjaga, memelihara, dan meningkatkan kesehatan (Umaroh, dkk, 2016).

Salah satu bagian dari PHBS adalah mencuci tangan memakai sabun sebelum dan sesudah melakukan suatu kegiatan. Mencuci tangan yang baik adalah dengan mengikuti 7 langkah membersihkan tangan sesuai prosedur yang benar untuk membunuh kuman penyebab penyakit. Dengan mencuci tangan memakai sabun baik sebelum makan atau pun sebelum memulai pekerjaan, akan menjaga kesehatan tubuh dan mencegah penyebaran penyakit melalui kuman yang menempel di tangan (Andriansyah, dkk, 2013).

Agar efektif, WHO (2009) telah menetapkan langkah-langkah cuci tangan pakai sabun sebagai berikut: membasahi kedua tangan dengan air mengalir, beri sabun secukupnya, menggosokan kedua telapak tangan dan punggung tangan, menggosok sela-sela jari kedua tangan, menggosok kedua telapak dengan jari-jari rapat, jari-jari tangan dirapatkan sambil digosok ke telapak tangan, tangan kiri ke kanan, dan sebaliknya, menggosok ibu jari secara berputar dalam genggaman tangan kanan, dan sebaliknya, menggosokkan kuku jari kanan memutar ke telapak tangan kiri, dan sebaliknya, basuh dengan air, dan mengeringkan tangan (WHO, 2009). 
Kelurahan Pangkalan Jati adalah sebuah kelurahan yang terletak di Kecamatan Cinere, Kota Depok, Jawa Barat, Indonesia. Pangkalan Jati berbatasan dengan : Bagian utara berbatasan dengan Kelurahan Pangkalan Jati Baru yang masih dalam bagian Kecamatan Cinere, bagian barat berbatasan dengan Kelurahan Pondok Cabe Kota Tangsel Provinsi Banten, bagian selatan berbatasan dengan Kelurahan Limo dan bagian sebelah timur berbatasan dengan Kelurahan Gandul.

PHBS pada tatanan rumah tangga dinilai berdasarkan 16 indikator yang meliputi 9 indikator perilaku dan 7 indikator lingkungan. Sembilan indikator perilaku ini adalah (1) Perilaku tidak merokok, (2) Persalinan oleh Nakes, (3) Immunisasi, (4) Penimbangan Balita, (5) Sarapan Pagi, (6) Kepersertaan Dana Sehat, (7) Kebersihan Mencuci Tangan, (8) Kebersihan Menggosok Gigi, (9) Olah Raga. Sedangkan Indikator Lingkungan pada PHBS adalah (1) sarana air bersih, (2) Jamban, (3) Tempat Sampah, (4) Sarana Pembuangan Air Limbah, (5) Ventilasi Rumah, (6) Kepadatan Rumah, (7) Lantai Rumah (Septarini, dkk, 2015).

Perilaku hidup bersih dan sehat merupakan cerminan pola hidup keluarga yang senantiasa memperhatikan dan menjaga kesehatan seluruh anggota keluarga. PHBS adalah semua perilaku yang dilakukan atas kesadaran sehingga anggota keluarga atau keluarga dapat menolong dirinya sendiri di bidang kesehatan dan berperan aktif dalam kegiatan-kegiatan kesehatan di masyarakat. Mencegah lebih baik daripada mengobati, prinsip kesehatan inilah yang menjadi dasar pelaksanaan Program PHBS (Septarini, dkk, 2015).

Teknik khusus mencuci tangan pakai sabun dalam 7 langkah. Pengertian cuci tangan 7 langkah adalah tata cara mencuci tangan menggunakan sabun untuk membersihkan jari - jari, telapak dan punggung tangan dari semua kotoran, kuman serta bakteri jahat penyebab penyakit. Tanggal 15 oktober adalah hari cuci tangan sedunia pakai sabun yang dicanangkan oleh PBB sebagai salah satu cara menurunkan angka kematian balita serta mencegah penyebaran penyakit. Manfaat melakukan 7 langkah mencuci tangan yaitu membersihkan dan membunuh kuman yang menempel secara cepat dan efektif karena semua bagian tangan akan dicuci menggunakan sabun (Septarini, dkk, 2015).

Cara Cuci Tangan 7 Langkah Pakai Sabun Yang Baik dan Benar. Basahi kedua telapak tangan setinggi pertengahan lengan memakai air yang mengalir, ambil sabun kemudian usap dan gosok kedua telapak tangan secara lembut.

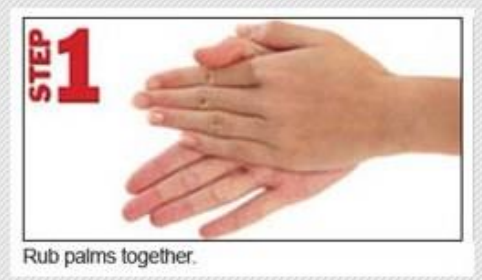

Usap dan gosok juga kedua punggung tangan secara bergantian

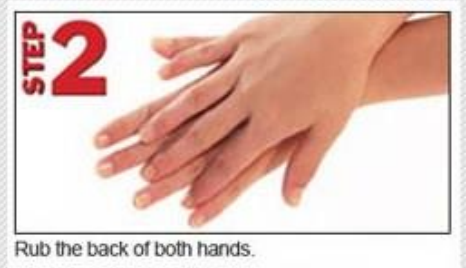


Jangan lupa jari-jari tangan, gosok sela-sela jari hingga bersih

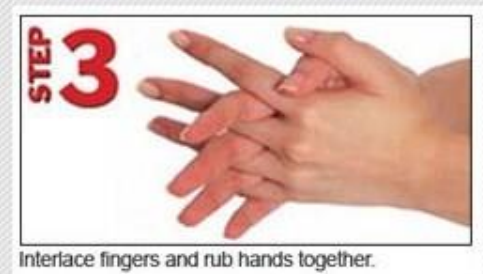

Bersihkan ujung jari secara bergantian dengan mengatupkan

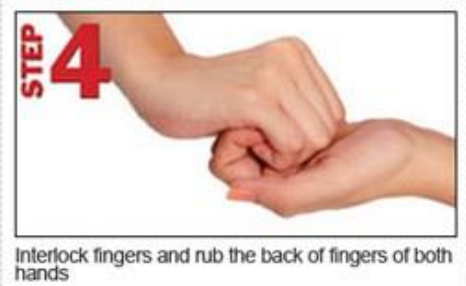

Gosok dan putar kedua ibu jari secara bergantian

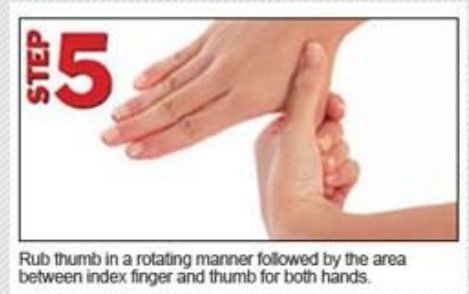

Letakkan ujung jari ke telapak tangan kemudian gosok perlahan

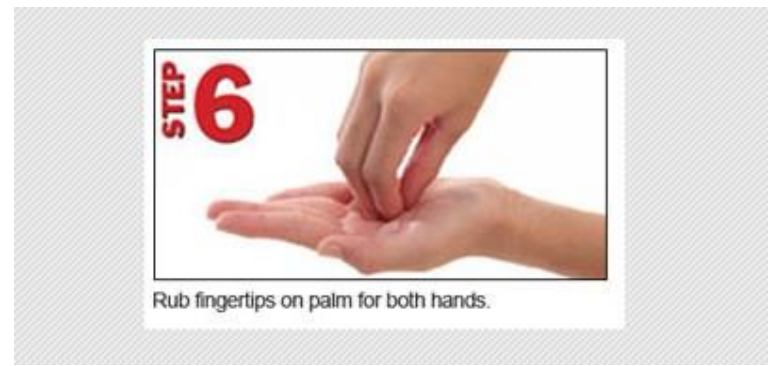

Bersihkan kedua pergelangan tangan secara bergantian dengan cara memutar, kemudian diakhiri dengan membilas seluruh bagian tangan dengan air bersih yang mengalir lalu keringkan memakai handuk atau tisu. 


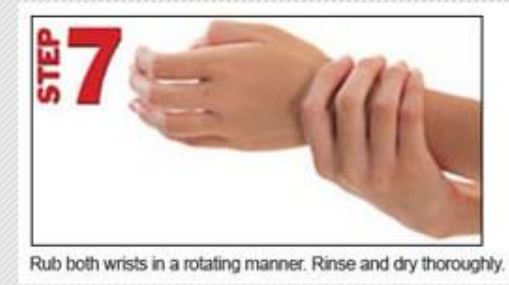

Penggunaan sabun khusus cuci tangan baik berbentuk batang maupun cair sangat disarankan untuk kebersihan tangan yang maksimal. 7 langkah mencuci tangan di atas umumnya membutuhkan waktu 15 - 20 menit. Pentingnya mencuci tangan secara baik dan benar memakai sabun adalah agar kebersihan terjaga secara keseluruhan serta mencegah kuman dan bakteri berpindah dari tangan ke tubuh anda.

Pada survey pendahuluan yang dilakukan pada TPA di RT 007/RW 007 Desa Pangkalan Jati mengenai cara mencuci tangan memakai sabun, ditemukan bahwa tingkat pengetahuan dan ketrampilan anak anak mengenai cara mencuci tangan memakai sabun masih rendah. Oleh karena itu kami Tim Pengabdian Kepada Masyarakat Fakultas Kedokteran Univesitas Pembangunan Nasional "Veteran" Jakarta bermaksud untuk melakukan pelatihan cara mencuci tangan menggunakan sabun sebagai salah satu perilaku hidup bersih dan sehat untuk dapat mencegah berbagai penyakit yang diakibatkan oleh higienitas yang kurang.

Berdasarkan analisis situasi dan hasil survey pendahuluan yang dilakukan permasalahan yang dihadapi mitra adalah rendahnya pengetahuan dan ketrampilan dalam perilaku hidup sehat dan bersih terutama perilaku mencuci tangan menggunakan sabun, masih sangat rendah.

\section{TINJAUAN PUSTAKA}

Pembangunan kesehatan adalah salah satu bagian penting dari pembangunan nasional yang mempunyai peranan besar dalam menentukan keberhasilan pencapaian tujuan pembangunan nasional. Pembangunan kesehatan yang dilakukan dapat meningkatkan kualitas sumber daya manusia yang ditandai dengan tingkat kesehatan penduduk yang meningkat. Upaya promotif dan preventif dalam rangka meningkatkan derajat kesehatan bangsa dan masyarakat dapat dilakukan dengan penerapan perilaku hidup bersih dan sehat (Riskesdas, 2013).

Kebiasaan mencuci tangan dengan menggunakan sabun dan air mengalir, adalah bagian dari perilaku hidup sehat yang merupakan salah satu dari tiga pilar pembangunan bidang kesehatan yakni perilaku hidup sehat, penciptaan lingkungan yang sehat serta penyediaan layanan kesehatan yang bermutu dan terjangkau oleh semua lapisan masyarakat. Perilaku hidup sehat yang sederhana seperti mencuci tangan dengan sabun dan air mengalir merupakan salah satu cara untuk meningkatkan kesadaran masyarakat tentang pemeliharaan kesehatan pribadi dan pentingnya berperilaku hidup bersih dan sehat (Purwandari, dkk, 2013).

Cuci tangan sering dianggap sebagai hal yang sangat mudah di masyarakat, padahal cuci tangan bisa memberi kontribusi pada peningkatan status kesehatan masyarakat. Berdasarkan hal ini, terlihat bahwa anak-anak usia sekolah mempunyai kebiasaan kurang memperhatikan perlunya cuci tangan dalam kehidupan sehari-hari. Mereka biasanya langsung makan makanan yang mereka beli di sekitar sekolah tanpa cuci tangan terlebih dahulu, padahal sebelumnya mereka bermain-main. Perilaku 
tersebut tentunya berpengaruh dan dapat memberikan kontribusi dalam terjadinya suatu penyakit (Purwandari, dkk, 2013).

Cuci tangan merupakan tehnik dasar yang paling penting dalam pencegahan dan pengontrolan penularan infeksi. Cuci tangan dengan sabun secara konsisten dapat mengurangi diare dan penyakit pernafasan. Cuci tangan pakai sabun (CTPS) dapat mengurangi diare sebanyak $31 \%$ dan menurunkan penyakit infeksi saluran nafas atas (ISPA) sebanyak $21 \%$. Riset global juga menunjukkan bahwa kebiasaaan CTPS tidak hanya mengurangi, tapi mencegah kejadian diare hingga $50 \%$ dan ISPA hingga 45\% (Purwandari, dkk, 2013). Cuci tangan dengan menggunakan sabun lebih efektif dalam memindahkan kuman dibandingkan dengan cuci tangan hanya dengan mengggunakan air (Purwandari, dkk, 2013).

Melalui tangan kita sendiri segala bibit penyakit itu juga bisa memasuki mulut, lubang hidung, mata, atau liang telinga, karena kebiasaan memasukkan jari ke hidung, mengucek mata, mengorek liang telinga, bukan pada waktu yang tepat (pada saat tangan kotor), dan ketika jari belum dibasuh (belum cuci tangan). Hal ini penting untuk pengendalian risiko penyakit yang berhubungan dengan lingkungan, seperti penyakit diare, penyakit kecacingan, dan tifoid yang sebenarnya dapat dicegah dengan kebiasaan buang air besar di jamban, penyediaan air minum dan kebiasaan mencuci tangan dengan sabun setelah buang air besar dan sebelum menjamah makanan (Septarini, dkk, 2015).

Riset Kesehatan Dasar (Riskesdas) Tahun 2013 menunjukkan bahwa rumah tangga di Indonesia yang mempraktekkan PHBS (Perilaku Hidup Bersih Sehat) rumah tangga baik mencapai 32,3\%. Dengan proporsi tertinggi pada DKI Jakarta $(56,8 \%)$ dan terendah pada Papua (16,4\%). Terdapat 20 dari 33 provinsi yang masih memiliki rumah tangga PHBS baik di bawah proporsi nasional, dan Yogyakarta ada pada urutan ke tiga setelah Jakarta menduduki peringkat pertama. Beberapa indikator yang digunakan dalam Riskesdas 2013 ini berbeda dengan indikator yang digunakan dalam Riskesdas 2007, sehingga tidak bisa menggambarkan kecenderungan kenaikan atau penurunan proporsi rumah tangga ber-PHBS. (Riskesdas, 2013).

Terdapat 10 indikator PHBS tatanan rumah tangga menurut Riskesdas (2011) yaitu : (1) Pertolongan persalinan oleh tenaga kesehatan, (2) Bayi diberi ASI ekslusif, (3) Menimbang bayi setiap bulan, (4) Ketersediaan air bersih, (5) Mencuci tangan dengan air bersih dan sabun, (6) Menggunakan jamban sehat, (7) Memberantas jentik sekali seminggu, (8) Makan buah dan sayur setiap hari, (9) Melakukan aktivitas fisik setiap hari, dan (10) Tidak merokok didalam rumah (Kemenkes, 2014).

Gerakan mencuci tangan memakai sabun dan air mengalir adalah suatu kegiatan sebagai upaya preventif dalam melindungi anak-anak dari berbagai penyakit menular. Mencuci tangan menggunakan sabun dan air mengalir dapat dilakukan pada waktu-waktu berikut: sebelum dan sesudah makan, setelah buang air kecil dan air besar, setelah bermain/memberi makan/memegang hewan. Mencuci tangan memakai sabun dan air mengalir yang dipraktikkan secara tepat dan benar merupakan cara termudah dan efektif untuk mencegah berjangkitnya penyakit. Mencuci tangan dengan air dan sabun dapat lebih efektif menghilangkan kotoran dan debu secara mekanis dari permukaan kulit dan secara bermakna mengurangi jumlah mikroorganisme penyebab penyakit seperti virus, bakteri dan parasit lainnya pada kedua tangan (Risnawaty, 2016).

Hendrik L. Blum di dalam Notoatmodjo (2010) secara jelas mengungkapkan bahwa terdapat empat faktor utama yang berkaitan dalam derajat kesehatan seseorang, kelompok dan masyarakat yaitu perilaku, pelayanan kesehatan, lingkungan dan keturunan atau herediter. Faktor - faktor tersebut memiliki keterkaitan dalam mempengaruhi derajat kesehatan masyarakat dan kesehatan perorangan. 
Diantara empat faktor tersebut factor determinan yang paling berpengaruh besar adalah faktor perilaku manusia dan disusul faktor lingkungan pada urutan kedua. Hal ini dapat terjadi akibat faktor perilaku memiliki pengaruh lebih besar dari faktor lingkungan sehingga lingkungan hidup manusia juga sangat dipengaruhi oleh perilaku masyarakat (Notoatmodjo, 2010).

Indikator PHBS (Perilaku Hidup Bersih dan Sehat) salah satunya mencuci tangan dengan sabun dan air mengalir yang merupakan sekumpulan perilaku yang dilakukan karena kesadaran dari hasil pembelajaran, yang membuat individu atau keluarga dapat menjaga dan memelihara kesehatan serta berperan aktif untuk mewujudkan masyarakat sehat. Salah satu pilar utama dalam Indonesia Sehat dan merupakan salah satu strategi untuk mengurangi beban negara dan masyarakat terhadap pembiayaan kesehatan yaitu PHBS (Kemenkes RI, 2014).

Menggunakan sabun saat mencuci tangan diketahui sebagai salah satu upaya pencegahan penyakit dan penularan penyakit. Hal ini dilakukan karena tangan merupakan agen yang membawa kuman dan menyebabkan patogen berpindah dari satu orang ke orang lain, baik dengan kontak tidak langsung maupun kontak langsung (menggunakan permukaan lain seperti handuk dan gelas) (Kemenkes RI, 2014).

\section{METODE PENERAPAN IPTEKS}

Berdasarkan uraian tersebut tim pengabdian kepada masyarakat bertujuan untuk melakukan program kemitraan masyarakat tentang cara mencuci tangan menggunakan sabun sebagai salah satu program hidup bersih dan sehat, untuk mencegah berbagai penyakit akibat higienitas yang rendah. Kurangnya pengetahuan dan ketrampilan dalam mencuci tangan menggunakan sabun menyebabkan kurangnya pemahaman terhadap bahaya rendahnya higienitas pribadi.

Oleh karena itu dibuat suatu program kemitraan masyarakat dengan melalukan penyuluhan dan pendampingan pelatihan cuci tangan menggunakan sabun bagi anak anak TPA RT 007/RW 007 Kelurahan Pangkalan Jati Kecamatan Cinere Kota Depok.

Pada pelaksanaan kegiatan PKM ini, langkah pertama, tim Pengabdian Masyarakat Fakultas Kedokteran UPNVJ melakukan pengkajian dengan survey awal kepada ke TPA di RT 007/RW 007 Keluarahan Pangkalan Jati Kecamatan Cinere Kota Depok . Berdasarkan survey tersebut didapatkan beberapa permasalahan yang dihadapi. Langkah kedua, menyiapkan materi kegiatan PKM. Langkah ketiga melakukan penyuluhan dan pelatihan cara mencuci tangan memakai sabun sebagai salah satu perilaku hidup bersih dan sehat. Tim pengabdian membuat kuisioner penilaian dengan memberikan pretest dan posttest, pelaksanaan penyuluhan dan pelatihan serta pendampingan anak anak TPA dalam praktek cuci tangan menggunakan sabun.

Evaluasi dilakukan untuk mengetahui sejauh mana efektivitas program ini untuk mencapai tujuan kegiatan yang telah dicanangkan. Adapun aspek yang dievaluasi meliputi : efektvitas pelaksanaan dilihat dari : manfaat kegiatan, tingkat pengetahuan dan pemahaman efektivitas pelatihan cuci tangan memakai sabun. Perubahan tingkat pengetahuan dan ketrampilan cuci tangan menggunakan sabun dilihat dari nilai pre dan pos tes, dan perubahan sikap serta praktek anak anak TPA dengan praktek cuci tangan menggunakan sabun.

Secara institusional FKUPNVJ memiliki kinerja yang sangat baik di dalam memenangi dan menjalankan program kompetitif bidang pengabdian kepada masyarakat. FKUPNVJ memiliki para ahli di bidang dan disiplin ilmu yang berkaitan dengan kesehatan 


\section{HASIL PENGABDIAN}

Tim Pengabdian Kepada Masyarakat telah melakukan pengabdian pada hari Selasa, tanggal 18 September 2018, bertempat di Kediaman Bapak Ketua RT 007/007 Kelurahan Pangkalan Jati Kecamatan Cinere, Kota Depok yang dipergunakan juga sebagai TPA bagi anak anak. Jumlah responden yang datang dan mengikuti pelatihan sebanyak 42 orang. Berikut karakteristik responden pengabdian:

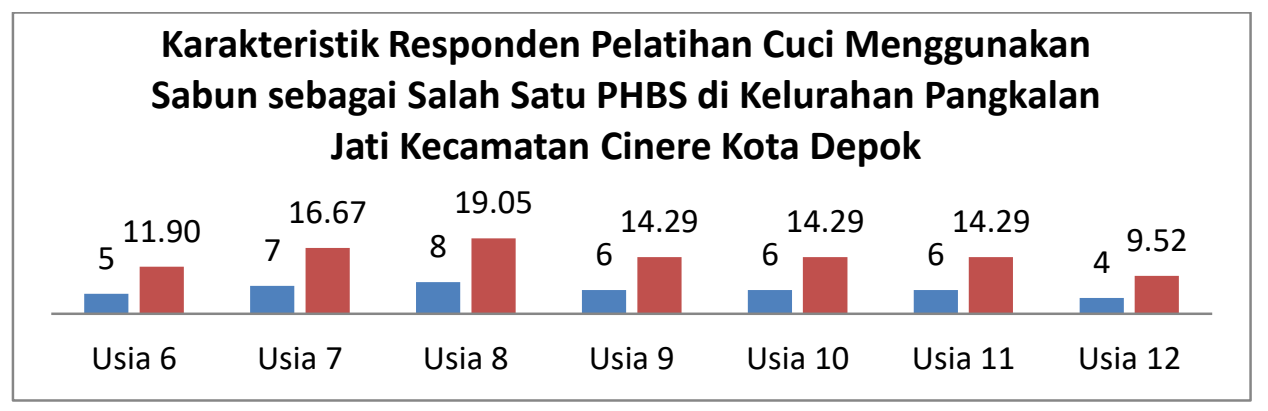

Gambar 1. Karakteristik Responden Pelatihan

Usia responden pelatihan pengabdian beragam, mulai dari usia 6 tahun $(11,90 \%)$, dan usia tertua adalah usia 12 tahun $(9,52 \%)$. Usia terbanyak dari responden adalah usia 8 tahun $(19,05 \%)$. Sebelum dilakukan penyuluhan dan pelatihan, peserta diberikan pretest untuk melihat tingkat pengetahuan responden terhadap cara mencuci tangan memakai sabun. Kemudian dilakukan penyuluhan dan pelatihan mencuci tangan dengan metode ceramah dan diskusi. Penyuluhan dan pelatihan menggunakan media powerpoint penyuluhan dan brosur cara mencuci tangan menggunakan sabun. Sambil dilakukan pelatihan, tim pengabdian juga melakukan diskusi dengan beberapa peserta pelatihan. Kemudian beberapa peserta penyuluhan diminta untuk maju ke depan untuk memperagakan cara mencuci tangan menggunakan sabun, sampai anak anak semua bisa melakukan cara mencuci tangan dengan sabun dengan benar.

Setelah itu dilakukan postest untuk melihat peningkatan pengetahun responden terhadap materi yang telah diberikan. Berikut hasil perbandingan nilai pretest dan posttest responden pelatihan mencuci tangan menggunakan sabun sebagai salah satu perilaku hidup bersih dan sehat.

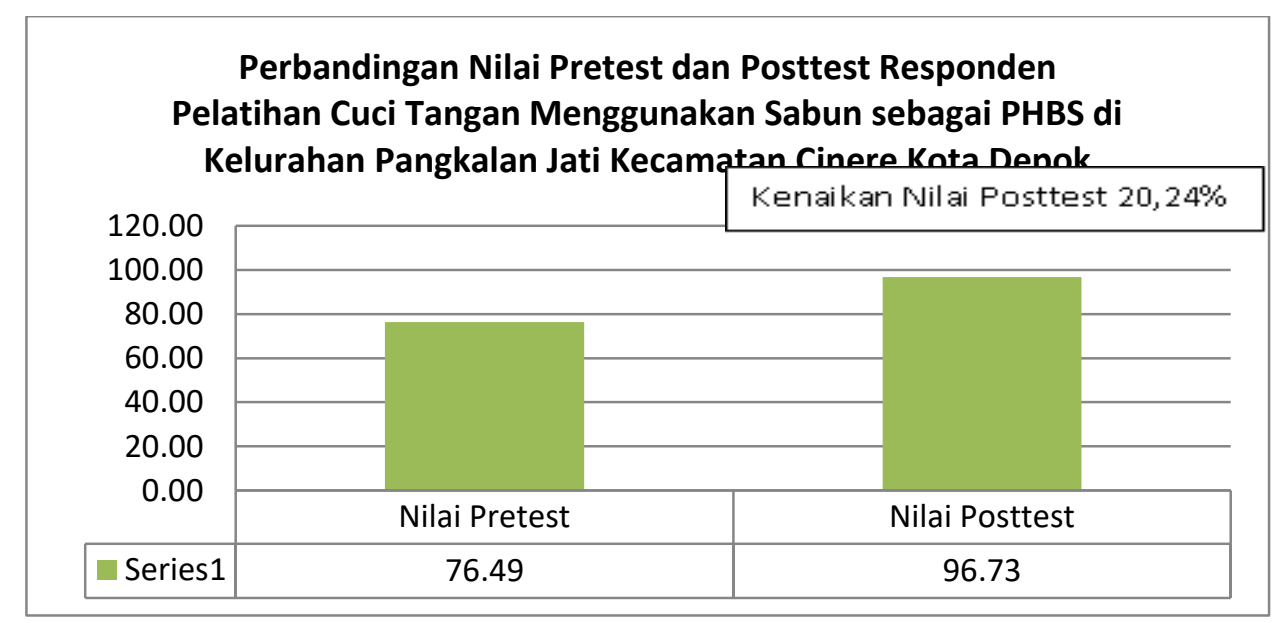

Gambar 2. Kenaikan Nilai Posttest 
Dari Gambar 2 diatas dapat dilihat bahwa nilai pretest sebesar 76,49\% dan setelah dilakukan penyuluhan dan pelatihan cara mencuci tangan dengan sabun sebagai salah satu perilaku hidup bersih dan sehat, kemudian dilakukan posttest, dapat dilihat bahwa nilai posttest responden meningkat menjadi 96,73\%. Terjadi peningkatan sebesar 20,24\%. Hal ini sesuai dengan harapan Tim Pengabdian bahwa diharapkan terjadi peningkatan pengetahuan sebesar $20 \%$.

\section{DISKUSI}

Tingkat pengetahuan dan ketrampilan responden meningkat setelah diberikan penyuluhan berupa materi mengenai cuci tangan menggunakan sabun. Pemberian penyuluhan ini meningkatkan pemahaman dan pengertian responden tentang hal-hal yang berkaitan dengan cuci tangan memakai sabun. Pengetahuan dapat diperoleh dari pengalaman langsung atau dari pengalaman orang lain yang disampaikan pada seseorang, selain itu pengetahuan juga dapat diperoleh melalui proses belajar yang didapat dari pendidikan kesehatan (Notoadmojo, 2010).

Pendidikan kesehatan melalui penyuluhan dan pelatihan merupakan serangkaian kegiatan komunikasi dengan menggunakan media dalam memberikan bantuan terhadap pengembangan potensi, yaitu fisik, emosi, sosial, sikap dan pengetahuan semaksimal mungkin (Notoadmojo, 2010).

Terjadi perubahan pengetahuan sebelum diberikan penyuluhan dan pelatihan dibandingkan dengan setelah diberikan penyuluhan dan pelatihan mencuci tangan menggunakan sabun. Minat responden untuk memahami isi penyuluhan juga sangat besar, sehingga penyuluhan tentang cuci tangan tersebut mudah diterima responden. Menurut WHO salah satu usaha atau strategi yang dapat dilakukan untuk memperoleh perubahan perilaku tersebut adalah dengan cara pemberian penyuluhan (WHO, 2010).

Pemberian informasi dalam bentuk penyuluhan dan pelatihan kesehatan merupakan suatu proses yang bermanfaat untuk menciptakan iklim atau kondisi yang mempengaruhi perilaku individu. Perilaku yang diharapkan tidak terbatas pada peningkatan pengetahuan, namun menciptakan sikap yang positif terhadap pesan yang disampaikan. Hal ini sesuai dengan tujuan spesifik dari pendidikan kesehatan yaitu perubahan kognitif, perubahan motivasi dan perubahan perilaku (Notoadmojo, 2010).

Pengetahuan seseorang tentang Mencuci tangan menggunakan sabun dapat menghilangkan sejumlah besar virus dan bakteri yang menjadi penyebab berbagai penyakit, terutama penyakit yang menyerang saluran pencernaan seperti diare dan saluran nafas seperti influenza. Hampir semua orang mengerti pentingnya mencuci tangan pakai sabun, namun masih banyak yang tidak membiasakan diri untuk melakukannya dengan benar pada saat yang penting (Septarini, 2015).

Mengapa kita harus cuci tangan dengan benar menggunakan sabun? karena mencuci tangan asalasalan dengan air saja tidak dapat membunuh kuman pada tangan. Banyak penyakit yang dapat dicegah dengan mencuci tangan seperti penyakit cacingan, diare, infeksi saluran napas, TBC, Sakit perut, muntaber, radang tenggorokan, amandel, asma, gangguan pernapasan, flu, hingga penyakit yang mematikan seperti SARS, flu burung, flu babi. Manfaat melakukan cuci tangan 7 langkah yaitu membersihkan dan membunuh kuman yang menempel secara cepat dan efektif karena semua bagian tangan akan dicuci menggunakan sabun (Umaroh, 2016).

Aktivitas mencuci tangan harus menggunakan sabun, karena sabun memiliki zat pembersih dan ada juga yang mengandung zat anti bakteri, dan zat pembersih lainnya.

1. Basahi kedua telapak tangan setinggi pertengahan lengan memakai air yang mengalir, ambil sabun kemudian usap dan gosok kedua telapak tangan secara lembut.

2. Usap dan gosok juga kedua punggung tangan secara bergantian. 
3. Jangan lupa jari-jari tangan, gosok sela-sela jari hingga bersih.

4. Bersihkan ujung jari secara bergantian dengan mengatupkan.

5. Gosok dan putar kedua ibu jari secara bergantian.

6. Letakkan ujung jari ke telapak tangan kemudian gosok perlahan.

7. Bersihkan kedua pergelangan tangan secara bergantian dengan cara memutar, kemudian diakhiri dengan membilas seluruh bagian tangan dengan air bersih yang mengalir lalu keringkan memakai handuk atau tisu (Septarini, 2015).

Waktu yang tepat dan benar untuk melakukan cuci tangan: Sebelum dan sesudah makan, Sebelum dan sesudah menyiapkan makanan, Sebelum dan sesudah mengganti popok bayi, Sebelum memasang lensa kontak, Sebelum merawat luka, Setelah ke toilet (buang air besar atau kecil), Setelah bersin atau batuk, Setelah menyentuh binatang, Setelah memegang sampah, Setelah bersentuhan dengan bendabenda di khalayak ramai seperti uang, gagang pintu, pegangan bus, alat absensi sidik jari, pegangan jembatan, tombol lift, dan lain-lainnya (Risnawaty, 2016).

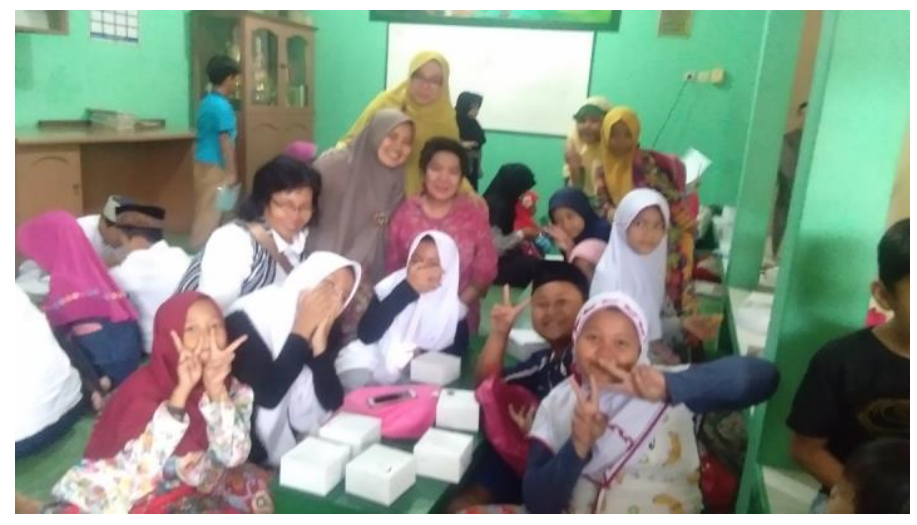

Gambar 3. Foto-foto kegiatan

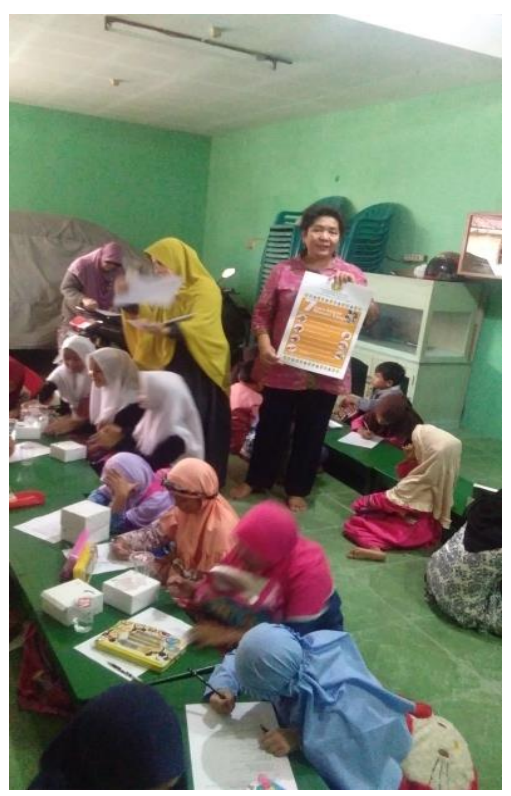

Gambar 4. Foto kegiatan 


\section{KESIMPULAN}

1. Setelah mendapatkan penyuluhan dan pelatihan tentang cara mencuci tangan memakai sabun pada anak anak TPA RT 007/RW 007 Desa Pangkalan Jati Kecamatan Cinere Kota Depok, terjadi peningkatan pengetahuan dan ketrampilan anak anak dalam ketrampilan mencuci tangan memakai sabun.

2. Peningkatan pengetahuan dan ketrampilan ini diketahui dari hasil pre test dan post test. Kenaikan nilai posttest sebesar 20,48\% dibandingkan dengan nilai pretest sebelum dilakukan penyuluhan dan pelatihan cara mencuci tangan memakai sabun.

\section{DAFTAR PUSTAKA}

1. Andriansyah, Y., Rahmantari, DN (2013). Penyuluhan dan praktik PHBS (perilaku hidup bersih sehat) dalam mewujudkan masyarakat desa peduli sehat. Seri Pengabdian Masyarakat 2013 ISSN: 2089-3086. Jurnal Inovasi dan Kewirausahaan. Vol 2 No. 1, Januari 2013. Hal 45-50.

2. Kementerian Kesehatan RI (2011). Indikator PHBS. Pedoman Pembinaan Perilaku Hidup Bersih dan Sehat (PHBS).

3. Notoadmodjo, S (2010). Ilmu perilaku kesehatan. Jakarta: Rineka Cipta.

4. Notoadmodjo, S. (2010). Promosi kesehatan teori dan aplikasi. Jakarta: Rineka Cipta.

5. Purwandari, R., Ardiana A., Wantiyah (2013). Hubungan antara perilaku mencuci tangan dengan insiden diare pada anak usia sekolah di kabupaten jember. Jurnal Keperawatan. ISSN: 2086-3071. Juli 2013: 122 - 130Versi online n/ URL: http://ejournal.umm.ac.id/index.php/keperawatan/article/view/2362. Vol 4, No 2.

6. Riskesdas (2013). Laporan Riset Kesehatan Dasar Republik Indonesia tahun 2013. Jakarta.

7. Risnawaty, G (2016). Faktor determinan perilaku cuci tangan pakai sabun (CTPS) pada masyarakat di tanah kalikedinding. Jurnal Promkes, Vol. 4, No. 1 Juli 2016: 70-81.

8. Septarini, NW (2015). Pemeriksaan dan Pengobatan Kecacingan pada Balita serta Sosialisasi Cuci Tangan Pakai Sabun pada Ibu Balita di Wilayah Muntigunung Kauh, Kubu, Karangasem. Program Study Ilmu Kesehatan Masyarakat Fakultas Kedokteran Universitas Udayana.

9. Umaroh AK, Hanggara HY, Choiri (2009). Gambaran Perilaku Hidup Bersih dan Sehat (PHBS) di Wialyah Kerja Puskesmas Bulu Kabupaten Sukoharjo 2015. 2015.

10. WHO World Health Organization (2009). Langkah mencuci tangan yang benar. 2009. 